\title{
POLICY LESSONS FROM RECENT GUN CONTROL RESEARCH
}

\author{
GARY KLECK* \\ I \\ INTRODUCTION
}

In 1976, a review of policy research on gun control concluded that "the few attempts at serious work are of marginal competence at best and tainted by obvious bias." It is hard to quarrel with this assessment, especially as it is applied to the most important and widely cited of the pre-1976 studies, the pro-control report to the Eisenhower Commission written by George Newton and Franklin Zimring. ${ }^{2}$ Since that time, however, considerable scholarly work has been completed, much of it of high quality and relevant to policy-related questions surrounding the legal regulation of firearms.

Some researchers make the policy implications of their work explicit, while others modestly choose to "let the facts speak for themselves." All too often, policy-relevant gun control research has been characterized by perfectly respectable data and research methods, but also by interpretations of the findings which either do not follow from the evidence or which are too vaguely and generally phrased to be useful in making policy. This article reviews the body of recent gun control research and points out some of the more important, albeit tentative, implications for public policy.

Although a broader definition could be employed, the term "gun control" is used in this article to refer to laws aimed at limiting possession of firearms, either among the general public or among specific segments of the population. This definition includes laws requiring a license or permit to purchase, own, or possess guns and laws totally prohibiting civilian ownership of all guns or of specific types of guns such as handguns in general or "Saturday Night Specials" in particular. The term as used here does not cover laws regulating the use of guns, such as prohibitions against carrying them, firing them within city limits, or using them to further a crime (for example, laws mandating additional or enhanced penalties for use of a gun in the commission of a felony). Most such measures are not a significant part of the gun control debate. Indeed, the generally anti-gun control National Rifle

\footnotetext{
Copyright $(1986$ by Law and Contemporary Problems

* Associate Professor, School of Criminology, Florida State University.

1. Bruce-Briggs, The Great American Gun IVar, 45 Pub. INTERest 37, 37 (1976).

2. G. Newton \& F. Zimring, Firearms and Violence in American Life (1969) (staff report to the National Commission on the Causes and Prevention of Violence).
} 
Association strongly supports additional penalties for the use of guns in crimes.

\section{II}

\section{The Relationship Between Violence and the AvaIlability of GuNS}

The first issue which must be addressed is why society should want to regulate firearms. This question is not as foolish as it may seem, since it is by no means obvious how, or even whether, the availability of firearms affects levels of violence. There are three ways in which the availability of guns might increase crime and violence: assault-instigating effects, crime-facilitating effects, and assault-intensifying effects. The term "assault-instigating effects" refers to the possibility that the sight of a gun, or possession of a gun, could stimulate or trigger assaults which otherwise would not have occurred. It has been asserted that stimuli commonly associated with aggression, such as guns, can elicit aggression from people ready to act aggressively, especially angry people. The literature on this subject has been reviewed elsewhere, ${ }^{3}$ so only brief remarks are necessary here. The studies are almost equally divided between those concluding that there is a "weapons effect" and those indicating that there is not. In any case, the bulk of this literature is irrelevant to concerns about the effect of guns in actual assaults because of the artificiality of the circumstances in which the weapons effect experiments were conducted. Most of the studies involved laboratory experiments in which confederates of the experimenters angered subjects, who were then given an opportunity to act aggressively toward the confederates, for instance, by giving them electrical shocks during a "learning experiment." A gun would be present for some subjects and was either left unexplained (not associated with anyone in the experiment) or was associated with the confederate, the "victim" of the subjects' aggression. Even when experiments were done in naturalistic field conditions, the gun was never in the possession of, or otherwise associated with, the subjects whose aggression was being measured. Consequently, these studies at best simulate aggression against persons with guns. Even for this limited issue, however, it is highly doubtful that many people will accept the conclusion that angry people will be more likely to attack another person if the potential victim is armed. This conclusion contradicts too much real-life experience of police officers, soldiers, criminals, and ordinary civilians, who have successfully inhibited the aggression of others by the display of a firearm.

The weapons effect literature sheds little light on whether a person's possession of a gun or other weapon can trigger his or her own aggression. Currently, the available evidence is compatible with the assertion that guns are as likely to inhibit aggression as to stimulate it. ${ }^{4}$ Although his finding may

3. See, e.g., Kleck \& Bordua, The Factual Foundation for Certain Key Assumptions of Gum Control, 5 LAW \& Pol'y Q. 271 (1983).

4. Id. at 274-78. 
have other explanations, Philip J. Cook observed that robbers armed with guns are far less likely to assault their victims than either robbers armed with other weapons or unarmed robbers. Twenty-two percent of robbers with guns, thirty-nine percent of those with knives, sixty percent of those with other weapons, and seventy-four percent of unarmed robbers attacked their victims. ${ }^{5}$ This is a commonplace finding, which agrees with earlier studies. ${ }^{6}$ If guns trigger assaults among people ready to act aggressively in real life, this tendency certainly is not in evidence among robbers.

The term "crime-facilitating effects" refers to the possibility that the possession of a gun may make possible or make easier a crime that a criminal already wanted to commit but might not have committed without the gun. For example, a gun can make it possible for a small man to attack a bigger man: "Colonel Colt made every man six feet tall." Similarly, a gun could facilitate an attack by a woman against a man. A gun may also make it possible for a man to commit a specific robbery even though he might not have thought that he would have had a reasonable chance of pulling it off without a gun. In these situations, the gun does not affect motivation or drive to commit the crime, but rather provides a tool that reduces risk to the criminal and improves chances for sucessfully manipulating the victim.

Cook has shown that guns are most likely to be used in assaults involving "weak" attackers and "strong" victims-attacks by females against males are more likely to involve guns than attacks with other gender combinations, and attacks by elderly persons against victims in their "prime" are more likely to involve guns than attacks with other age combinations. ${ }^{7}$ While it is impossible to know from these facts whether some weak attacker-strong victim assaults would not have occurred in the absence of guns, the findings are compatable with the facilitation hypothesis. Gun availability could increase the overall frequency of attacks by enabling weaker people to attack stronger ones.

Cook has also provided some indirectly relevant evidence about robberies. A series of studies found that availability of guns has no effect on the robbery rates in large cities ${ }^{8}$ but that it does appear to affect the kinds of targets robbed. ${ }^{9}$ Gun possession seems to provide the tactical edge that allows robbers to attack more lucrative, but less vulnerable targets-such as commercial targets rather than individuals on the street, males rather than females, groups of victims rather than single victims, and victims in their

5. Cook, Reducing Injury and Death Rates in Robbery, 6 PoL'y ANalysis 21,33 (1980).

6. See, e.g., J. Conklin, Robbery and the Criminal Justice System 117 (1972); The Prevention and Control of Robbery 77 (F. Feeney \& A. Weir eds. 1973); A. Normandeau, Trends and Patterns in Crimes of Robbery 201 (1968) (unpublished Ph.D. dissertation, available at University of Pennsylvania).

7. Cook, The Role of Firearms in l'iolent Crime, in Criminal Violence 255-57 (M. Wolfgang \& N. Weiner eds. 1982). (1979).

8. Cook, The Effect of Gun Availability on Robbery and Robbery .Murder, 3 PoL'y STud. Rev. ANN. 743

9. Cook, a Strategic Choice Analysis of Robbery, in SAmple Surveys of the Victims of Crime 173. 186 (W. Skogan ed. 1976) [hereinafter cited as SAmpte Surveys]: Cook, supra note 5. at 42. 
middle years rather than the very young or the very old. ${ }^{10}$ These findings strongly suggest that reducing gun ownership among the crime-prone, even it if could be achieved, would result in no change in the frequency or number of robberies but would shift the burden of robbery from those best able to bear it to those least able to do so-a policy outcome of dubious value.

The term "assault-intensifying effects" refers to the assertion that when assaults occur, for whatever reason and in whatever circumstances, the use of a gun increases the severity of any resulting injuries and the probability of the victim's death, compared to what would have occurred had a likely substitute weapon, such as a knife or fists, been used. This is the least controversial of the possible effects of guns on crime, yet it too is subject to dispute concerning its magnitude.

How much deadlier are guns compared to probable substitute weapons such as knives? The most widely cited estimate is implied in the conclusions of George Newton and Franklin Zimring regarding assaults: "When a gun is used, the chances of a death are about five times as great as when a knife is used." Perhaps what is most noteworthy about this statement is its misleading phrasing. While leading many readers to believe that guns are five times as deadly as knives, the authors avoid saying so in any explicit way. Critics have pointed out that much of the difference in fatality rates between gun assaults and knife assaults could be due to the greater seriousness of intent to injure or kill among users of guns. ${ }^{12}$ People choose more serious methods of assault when they are more serious about hurting their victims, even when there is little premeditation or conscious weighing or selfexamination of motives by assaulters. ${ }^{13}$ Since more seriously inclined attackers can be expected to injure more seriously, regardless of weapon choice, the fact that fatality rates in gun assaults are higher than in knife assaults does not necessarily indicate that guns themselves are even slightly more deadly than knives, regardless of how self-evident the greater deadliness of guns may seem.

A meaningful comparison of weapon deadliness requires some comparability of intent and motive between users of different weapons. There is no reason to believe that such comparability prevailed in the heterogenous samples of assaults examined in the Newton and Zimring discussion and in the study by Zimring ${ }^{14}$ on which it was based. For example, in one of Zimring's own tables, a simple recomputation of his percentages shows that gun assaulters are substantially more likely to be male than knife assaulters (eighty-seven percent and sixty-five percent, respectively), ${ }^{15}$ a

10. Cook, A Strategic Choice Analysis of Robbery, in Sample Surveys, supra note 9, at 181; Cook, supra note 5 , at 43 .

11. G. Newton \& F. ZimRing, supra note 2, at 48.

12. Hardy \& Stompoly, Of Arms and the Law, 51 Chi.-Kent L. Rev. 62, 104 (1974).

13. See Kleck \& Bordua, supra note 3, at 272-74.

14. Zimring, Is Gun Control Likely to Reduce t'iolent Killings?, 35 CHI.-KeNT L. REv. 721 (1968).

15. Id. at 727 . 
difference of obvious significance given the enormous difference in homicidal behavior between men and women. ${ }^{16}$

Another way of validating the assault-intensifying hypothesis would be to demonstrate a positive correlation between aggregate levels of gun ownership and homicide rates. Studies of this issue have produced mixed results. ${ }^{17}$ In this author's studies, ${ }^{18}$ the pattern of findings suggested that gun ownership in the general public has no effect on homicide rates, although ownership within violence-prone groups may well affect homicide rates. ${ }^{19}$ It was not possible to determine if the result was due to an assault-intensifying effect, although this explanation seems plausible.

This article focuses exclusively on assaultive crimes and robbery for the simple reason that gun use in other crimes is slight. For example, in 1979 only about nine percent of rape offenders were armed with a gun. ${ }^{20}$ The presence of a gun in even these few rapes was often incidental and not necessary in the commission of the crime when rapists could rely on their superior size and strength to overpower their victims. Guns are also unnecessary in the commission of burglary because it is a crime of stealth. Although there is little solid information on the subject, it seems that few burglars carry firearms, based on the extremely small number of victims who are shot when a confrontation with the burglar occurs. In New York City, for example, only twenty burglary victims were killed (and not necessarily with guns) between 1958 and 1967, even though there were 150,000 burglaries reported in 1967 alone. ${ }^{21}$ It has been estimated that by 1973 a million New York City residents owned guns. ${ }^{22}$ Consequently, gun availability likely has only a negligible effect on increasing rape or burglary.

The relationship between gun availability and crime and violence is still very much in doubt, but can be summarized as follows. No reliable evidence indicates that guns have any net assault-instigating effects, or that aggressioneliciting effects are any more common than inhibiting effects. Guns probably have a crime-facilitating effect on robberies against less vulnerable targets, but no effect on the overall robbery rates. In other words, guns cause some robbers to shift from one target type to another, without, however, increasing the frequency with which they rob. Evidence is consistent with the idea that guns facilitate some assaults and thus gun availability could conceivably

16. See, e.g., Federal Bureau of Investigation, 1980 Uniform Crime Reports, Crime in the UNITED STATES 178 (1981) [hereinafter cited as UCR (date) (the FBI has published a number of these reports; the specific publication will be identified by the year of coverage)].

17. These studies are reviewed in Kleck. The Relationship Between Gun Owmership Levels and Rates of Fiolence in the l'nited Slates, in Firearms and Violence: Issues of Public Policy 99 (D. Kates ed. 1984) [hereinafter cited as Firearms and VIOLENCE].

18. Kleck, Capilal Punishment, Gun Ownership, and Homicide, 84 AM. J. Soc. 882 (1979); Kleck, supra note 17.

19. Kleck, supra note 17, at 121-22, 131; Kleck, supra note 18, at 883-84.

20. According to the national victimization survey for $1980,26.9 \%$ of rapes involved armed offenders, and $34.1 \%$ of the attackers used a firearm. U.S. BurEau of Justice Statistics, C.riminal. Victimization in the United States 1982, at 60-61 (1984). [.269 x .341 =.09 or nine percent.]

21. G. Newton \& F. Zimring, supia note 2, at 62 .

22. Vera Institute of Justice, Felony Arrests 115 (rev. ed. 1981 ). 
increase assault frequency. Finally, although an assault-intensifying effect of gun availability is plausible, there is no compelling evidence demonstrating its existence or magnitude.

\section{III}

\section{Whose Gun Ownership Should Be Controlled?}

Gun control measures can be aimed at preventing gun possession either among the general public or by individuals in some more restricted, presumably high-risk, subset of the population. A prohibition on private ownership of handguns or a restrictive licensing or permit system administered to reduce drastically possession by ordinary citizens would be examples of the former, while a permissive licensing or permit-to-purchase system from which only high-risk groups are excluded would exemplify the latter. The first alternative, the "blunderbuss" approach, makes most sense to people who believe that it is impossible to distinguish between low-risk and high-risk candidates for gun ownership, that everyone is a potential killer, and that serious acts of violence and other criminal acts committed with guns are common among people with no previous record of violence. Gun control advocates like to proclaim that domestic homicides and other killings involving persons who know each other are common. The implication is that such killings involve people who could not have been identified in advance as anything other than ordinary citizens, who one day got angry and went over the edge. The policy implications of such a picture are twofold: that all citizens must be excluded from gun ownership to prevent such tragedies, and that gun control laws can be effective even if hardcore criminals ignore them, since compliance among "ordinary people" will produce significant reductions in numbers of homicides.

In fact, very few homicides are committed by people who have no prior history of violence. The popular image of the model citizen who one day goes berserk and kills a family member is largely a media-created myth maintained by newspeople enamored with the dramatic contrast between extremely violent acts and supposedly peaceful backgrounds. For example, in news stories about the Texas Tower killer, Charles Whitman, reporters invariably found a way to mention the fact that Whitman had been a choir boy and an Eagle Scout. Left unsaid, or relegated to the back pages, were the facts that he was raised in a violent home, had repeatedly beaten his wife, and been court-martialed in the Marines for fighting. ${ }^{23}$

The apparently "nonviolent" killer is a rare exception to a rather mundane general rule: People who are seriously violent in the present almost invariably have been seriously violent in the past. While most violent acts escape the attention of authorities and are thus not made a part of official written records, most arrested killers have committed enough violent acts in the past to have been previously arrested or convicted. Data reviewed by Kleck and

23. A. Bandura, Aggression: A Social Learning Analysis 180 (1973). 
Bordua indicate that perhaps seventy to seventy-five percent of domestic homicide offenders have been previously arrested and about half previously convicted. ${ }^{4} 4$ An even more meaningful measure of previous violence indicated that ninety percent of domestic homicides in Kansas City had been preceded by previous police "disturbance calls" at the same address, with a median of five calls per address. Rather than being isolated outbursts, violent acts are almost always part of a continuing pattern of violent behavior, whether the violence is spouse or child abuse ${ }^{25}$ or armed robbery committed by "hardened criminals." 26

The most obvious policy implication of these facts is that reducing gun availability among "ordinary people" will do almost nothing to reduce violent crime. At best, it will act indirectly to reduce the availability of guns to criminals who might steal or otherwise obtain them from legal owners. Unfortunately, "blunderbuss" measures would inevitably have their greatest effect in reducing gun availability among the law-abiding, since it is, by definition, the law-abiding who are most likely to comply with gun control laws or, for that matter, any other laws. Compliance among criminals, on the other hand, would be low, given previous experience with more limited laws. Among the "hardened criminals" who reported previous gun possession when questioned in a recent prison survey, only fifteen percent claimed to have ever even applied for a permit to purchase or carry any of the guns, even though about ninety-one percent of the sample were imprisoned in states with provision for one or the other permit and thirty-two percent were in states with both. ${ }^{27}$ For the entire prison sample, eighty-two percent agreed with the statement that "Gun laws affect only law-abiding citizens; criminals will always be able to get guns." 28

The alternative to the blunderbuss measures is more selective "targeted" measures aimed at high-risk subsets of the population such as those with official records of previous criminal behavior. Laws which either prohibit ownership or possession by such persons or which deny them required licenses or purchase permits are examples of targeted measures. These measures have the advantage of not pointlessly denying guns to people who will never commit a serious violent act in their lives, but the concomitant disadvantage of inevitably permitting legal access to guns among some violent people without prior criminal convictions.

However common previous violent and criminal behavior is among the currently violent, many violent people nonetheless have no previous criminal convictions. Since a simple arrest would not be adequate to constitutionally

24. Kleck \& Bordua, supra note 3 , at 293.

25. See generally M. Strauss, R. Gelles \& S. Steinmetz, Behind Closed Doors: Violence in THE AMERICAN FAMILY' (1980).

26. See generally M. Dietz, Killing for Proftr: The Social Organization of Felony Homicide (1983).

27. J. Wright \& P. Rossi, Codebook for Prison Survey (1983) (marginals for question 114) (unpublished) (this author's computations regarding prisoners in states with various gun laws).

28. Id. (marginals for question 89). 
deny a person a privilege available to others, this means that guns could not be denied, under selective gun control measures such as permissive licensing laws, to about half of the people who will commit homicides in the near future. This assumes, however, that the percentage of offenders with a prior conviction remains constant. If the necessary resources were committed, there would be nothing to prevent police officers and prosecutors from insuring that a higher number of violent people are convicted of an offense which prevents future legal gun ownership, even if they were then given probation or a suspended sentence. This would require a systematic reform of current practices, where domestic disturbances involving repeatedly violent people are usually treated as minor offenses or private family matters not calling for official processing. Nevertheless, even if the number of violent people with a previous conviction were raised, some would necessarily still remain without such a record, and thus qualify for legal gun acquisition under targeted measures like permissive licensing or permit-to-buy systems.

Under targeted gun control laws, various other groups besides convicted criminals may be prohibited from owning or acquiring guns. Typically excluded from gun possession are alcoholics, mentally ill or mentally retarded persons, illegal aliens, and drug addicts. Most such prohibitions are unjust, of doubtful constitutionality, impractical to apply, and pointless for preventing violent crime. There are no universally accepted medical or psychiatric definitions of mental illness, drug addiction, or alcoholism. Those definitions on which some experts manage to agree are too vague to be useful for legal purposes, making prohibitions based on them unconstitutional. Some states use more precise definitions of the prohibited categories, for instance, denying guns only to persons committed involuntarily to mental institutions. Few states have comprehensive registries of involuntary mental patients, alcoholics, drug addicts, or mentally retarded persons, however, making it difficult or impossible to check for such a status. ${ }^{29}$

Most mentally ill persons have no record of violence. Even among those so seriously ill as to require psychiatric hospitalization, only a minority have an official record of violence in the form of an arrest for a violent crime. ${ }^{30}$ Further, this minority is confined to that subset of patients who were identifiable as "high risk" by an arrest prior to hospitalization. One careful study found that among mental patients without a preadmission arrest, fewer than four percent were arrested for any crime during a postrelease followup period. ${ }^{31}$ Thus, violence potential above the minimal level characterizing the general public is limited to a small, identifiable minority of mentally ill persons. Even within this minority, many are already denied legal access to or possession of a gun by virtue of a criminal conviction. There is therefore little

29. Cook \& Blose, State Programs for Screening Handgun Buyers, 455 Annal.s 80 (1981).

30. Brown, Mental Patients as I'ictimizers and Iictims, in Deviants: Victims or Victimizers? 199208 (D. MacNamara \& A. Karmen eds. 1983).

31. Steadman, Vanderwyst \& Ribner, Comparing threst Rates of .Mental Patients and Criminal Offenders, 135 Aм. J. Psychiatry 1218-20 (1978). 
factual basis for a broad legal presumption of risk to the public applied indiscriminantly to the mentally ill population as a whole, with corresonding prohibitions on firearms acquisition or possession. Nevertheless, popular stereotypes about mental illness and its supposed connection to violence are likely to keep former mental patients in the prohibited category. A more reasonable alternative would be to maintain state registries on persons admitted to psychiatric hospitals specifically as a result of violent behavior (a minority of psychiatric admissions), and use this as a basis for denying gun ownership, possession, and acquisition. This group, as well as persons with a prior criminal conviction, fugitives from justice, and persons under the age of eighteen could be denied gun ownership on the basis of specific, constitutionally defensible criteria, using existing or easily established record systems. ${ }^{32}$

IV

\section{Deterrent and Defensive EfFectiveness of Civilian Gun Ownership}

Until recently, scholarly students of gun control did not pay serious attention to the possibility that guns have defensive value for their owners or for deterring criminal behavior. This omission is not surprising. For a long time, academic criminologists did not even attach merit to the idea that legal punishment deters criminals. Some preliminary work has been done recently, however, permitting a few tentative conclusions.

\section{A. Civilians Frequently Use Guns Against Criminals}

While occurences of gun use against criminals by civilians are not usually widely publicized and national statistics on their frequency are not published, they nonetheless occur often. First, civilians shoot many criminals-more than the police do. Unpublished data from the FBI indicate that 490 justifiable homicides by civilians were reported to the police in 1981, 422 of which were committed with guns. ${ }^{33}$ The FBI defines a justifiable civilian homicide as the killing of a felon by a private citizen during the commission of an independent felony, that is, a felony other than the assault on the citizen (such as when a woman shoots a rapist or when a shopkeeper shoots a robber). ${ }^{34}$ These figures underestimate defensive shootings, however, since the FBI does not count most self-defense killings by civilians as justifiable homicides, but rather as excusable homicides. ${ }^{35}$ Data from Detroit for the period 1975-1980 indicate that there were more than twice as many excusable homicides (nearly all of which presumably involved civilians, since police cases are almost invariably classified as justifiable) than civilian justifiable

32. See Cook \& Blose, supra note 29 , at $87-89$ (discussing the feasibility and cost of such sustems).

33. Federal Bureau of Investigation, Supplementary Homicide Reports (1983) (unpublished computer counts).

34. UCR (1980), supra note 16 , at 6 .

35. California Dep't of Justice, Homicide in California 1982. al 32 (1983). 
homicides (297 and 124, respectively). ${ }^{36}$ Some excusable homicides are accidental killings involving less culpability on the part of the responsible actor than would constitute negligence, but it is doubtful that many of these cases are accidents-while Detroit had forty-four excusable homicides in $1979,{ }^{37}$ it had only four accidental gun deaths that year. ${ }^{38}$ If it is conservatively assumed that there are twice as many civilian excusable selfdefense killings nationally as there are civilian justifiable homicides, this yields an estimate of 1,266 excusable self-defense or justifiable homicides by civilians with guns in 1981 . There are about 6.8 nonfatal gun assaults with injury for every gun homicide, ${ }^{39}$ so civilians committed an estimated 8,609 nonfatal justifiable or excusable woundings of criminals in 1981. The magnitude of these figures can be judged from the fact that police officers in the United States killed only 388 felons during the same period. ${ }^{40}$

The use of guns to shoot criminals, however, represents only a small minority of the defensive uses of guns. Most incidents involve a gun being used only to threaten, apprehend, or shoot at a criminal, or to fire a warning shot, without killing or wounding anyone. A 1978 national survey found that seven percent of the households in the United States reported that a member of the household had at some time in the past used a gun against another person for self-protection, excluding military or police experiences. ${ }^{1}$ This finding translates into over five million households, out of the seventy-seven million households in the country at the time of the survey.

A 1981 survey by liberal pollster Peter Hart found that twenty-three percent of American voters kept handguns in their homes and nine percent of these had used their handguns for self-protection in the past five years. ${ }^{42}$ With a total of 82.4 million households in the United States in 1981 , this

36. M. Dietz, supra note 26 , at 203 .

37. Id.

38. Unpublished tabulations from National Center for Health Statistics Mortality Detail File computer tape (on file with the author).

39. According to the national victimization survey for 1980 , there were 572,000 aggravated assaults with injury. Of all aggravated assaults, $92.4 \%$ involved armed offenders. It is assumed that the same percentage applies to assaults with injury. Among armed assaulters. $15.1 \%$ carried guns. Therefore, in 1980 there were an estimated $572,000 \times .924 \times .151=79,807$ nonfatal aggravated assault injuries involving guns. In that year, there were also 405.000 robberies with injury. $38.3 \%$ of which involved armed offenders, out of which $11.7 \%$ were armed with guns. UNITED STATES BUREAU of Justige Statistics, supra note 20 , at 22,57,58. Thus, there were an estimated $405,000 \times .383 \mathrm{x}$ $.117=18,148$ injuries resulting from robberies by offenders armed with guns, Not all of these instances necessarily involved injuries caused by robbers actually using their guns, but this is assumed to be the case. On the other hand, many of the assaults in which guns were used did not involve the firing of the gun but rather its use as a club. Consequently, the number of nonfatal gunshot wounds is necessarily less than the number of assaults involving guns. According to the Uniform Crime Reports there were 23,040 homicides in the United States in $1980.62 .4 \%$ of which involved guns. UCR (1981), supra note 16, at 11,41. Therefore, there were about $23,040 \times .624=$ 14,377 gun homicides. Thus, the ratio of nonfatal gun-related injuries to fatal gun injurics is $97,956 / 14,377$, or 6.8 to 1 .

40. Federal Bureau of Investigation, Supplementary Homicide Reports, supra note 33.

41. Decision/Making/Information, Attitudes of the American Fifctorate loward Gin Control. 1978, at 116 (1979).

42. R. McGuire \& B. Gotbaum, Manual for Public Enucation Cimpaicen on Handsin Violence 19 n.5 (June 1983) (prepared by the New York City Police Dep't and the Nat'l Alliance 
means that there were 18.9 million handgun-owning households, $1,707,000$ of which had used handguns defensively. Conservatively, assuming only one use per household, this finding implies that over 340,000 defensive uses of handguns occurred each year.

\section{B. Civilian Weapon Use Is Effective}

Victimization surveys have asked robbery and assault victims whether they resisted their victimizers, used weapons, were successful in preventing the crime, or were injured. The results indicate that for both robberies and assaults, the crime was less likely to be completed against victims who resisted with a gun or knife (the two weapons were considered together in the surveys), compared to those who did not resist. Furthermore, resisting victims were no more likely to be injured (even less likely, for assaults) than those who did not resist. ${ }^{43}$

Confirming this perspective, Don Kates' study of newspaper accounts of civilian and police defensive use of guns indicated that civilian use was generally more effective than police use. He analyzed every story concerning use of guns to interrupt or prevent crimes or apprehend criminals printed in forty-two of the nation's largest circulation newspapers during periods in 1975 and 1976. His results indicate that eighty-three percent of the civilian users were successful in preventing the crime, apprehending the criminal, or both, while the success rate was only sixty-eight percent for the police. ${ }^{44}$ It is not known whether cases not reported in newspapers are less likely to be successful, but there is no reason to believe any such bias would be different for cases involving police and those involving civilians.

No one knows how many criminals armed citizens apprehend each year, but many, possibly most, of the arrests for serious predatory crimes are the result of citizens who report the crime and identify the offender or provide a uniquely identifying piece of evidence such as the license plate number of a fleeing offender. ${ }^{45}$ Perhaps citizens take an even more active role in law enforcement than just mobilizing the police and identifying offenders. This role would conform with, albeit in an unorthodox way, the themes of students of social control and the law, who traditionally have argued that social order is more the result of the extralegal or informal actions of private citizens than of formal law enforcement agencies' activities. ${ }^{46}$

Against Violence) (citing a private poll by Peter D. Hart Research Associates, Inc. (Wash., D.C., OCt. 1981)).

43. Kleck \& Bordua, supra note 3, at 289.

44. D. Kates, Jr., Defensive Use of Guns by Police and Civilians (unpublished manuscripı).

45. See P. Greenwood, J. Chaiken \& J. Pétersilia, The Criminal Investigation Process 33 (1977); A. Reiss, The Police and the Public 11 (1971).

46. See, e.g., R. LaPiere, A Theory of Social Control (1954); W. Sumner, Folkways (1906). 
C. Criminals Perceive a Risk from Civilian Gun Use, Roughly Comparable in Magnitude to Their Perception of Risk from the Criminal Justice System

James Wright and Peter $H$. Rossi recently conducted an ambitious and sophisticated survey of known criminals concerning their gun use and opinions about gun control and related matters. ${ }^{47}$ Over 1800 prison inmates in ten states were interviewed in 1983. When these criminals were asked how often they thought about various things when getting ready to commit a crime, thirty-four percent reported that they thought often or regularly "that you might get shot by the police" and an identical thirty-four percent thought "that you might get shot by your victim." (Even the possibility of going to prison was considered regularly or often by only fifty percent of the sample.) Indeed, criminals worry about citizen gun use at least as much as they worry about the police; fifty-seven percent agreed that "[m]ost criminals are more worried about meeting an armed victim than they are about running into the police." Fifty-five percent also agreed that "[a] criminal is not going to mess around with a victim that he knows is armed"; eighty percent agreed that "[o]ne reason burglars avoid houses when people are home is that they fear getting shot during the crime"; and fifty-nine percent agreed that "[a] store owner who is known to keep a gun on the premises is not going to get robbed very often."'48

Wright and Rossi's survey results also confirm the picture of frequent gun use by civilians against criminals drawn from the general population surveys. Their findings indicate that thirty-seven percent of the criminals have personally confronted victims armed with guns and thirty-four percent have personally been frightened away, shot at, wounded, or captured by an armed victim. ${ }^{49}$ Wright and Rossi are not alone in obtaining such findings from interviews with criminals. Their results confirm those of earlier, less sophisticated and less extensive prison surveys. ${ }^{50}$

\section{The Perception of Risk Affects Criminal Behavior}

A variety of evidence supports the assertion that criminals are affected by civilian gun use. First of all, criminals say they behave differently because of civilian gun ownership. In the Wright and Rossi survey, thirty-nine percent of the criminals reported that they had at some time in the past decided not to commit a crime because they knew or believed the victim was carrying a gun, ${ }^{51}$ while an unstated number of convicted robbers and burglars interviewed in a California prison said they knew of specific cases when

47. J. Wright \& P. Rossi, supra note 27.

48. Id. (marginals for questions 71 and 89 ).

49. Id. (marginals for questions 90 and 91 ).

50. See Firman, In Prison Gun Survey the Pros are the Cons, Am. Ririceman, Nov. 1975, at I3; Richardson, .1/y/h \#2: Criminals Won $t$ Have Guns, True, July 1975, at 32; Link, No Handguns in . Morton Groze-Big Deal, Menard Time, Jan. 22, 1982, at 1 (prisoner newsletter for the Illinois Dep't of Corrections facility at Menard, Ill.).

51. J. Wright \& P. Rossi, supra note 27 (marginals for question 92). 
robberies were not committed because the prospective victim was known to be armed. ${ }^{52}$ As noted above, criminals in the Wright and Rossi survey said that burglars avoid occupied premises in committing burglaries at least partly because they fear getting shot. ${ }^{53}$ In this regard, Kleck and Bordua estimated that the risk of imprisonment for committing a burglary is less than one percent, yet some studies have concluded that this legal risk is sufficient to deter some burglars. Likewise, the low absolute frequency of burglars being shot does not preclude the possibility that civilian gun use will exert a deterrent effect anyway. ${ }^{54}$

Finally, analysis of real-life quasi-experiments suggests that changes in the perception of risk from civilian gun use can affect the frequency of various crimes. In 1966 the Orlando city police introduced a gun training program for civilian women in response to an increase in rapes. Although rape was on the increase in Florida and in the United States as a whole, the city of Orlando experienced an eighty-eight percent drop in the incidence of rape during the year following the onset of the gun training program. There was no similar drop in rape rates in surrounding areas and the Orlando decrease was far in excess of any previous one-year change in the city's rape rates, lending support to the hypothesis that the program and its accompanying publicity brought about the decrease in rape. ${ }^{55}$ One plausible interpretation of these events is that the gun training program heightened the awareness of victim gun ownership among potential rapists, reminding them of something which had always existed but which had not always been so salient. Similar results have occurred in connection with other gun training programs, apparently producing decreases in armed robbery in Highland Park, Michigan, drug store robberies in New Orleans, and grocery store robberies in Detroit. Also, in Kennesaw, Georgia, where a highly publicized city ordinance was passed requiring household gun ownership, burglaries dropped eighty-nine percent over the seven months immediately after passage of the law (as compared with the same period during the previous year). ${ }^{56}$

These findings have some interesting policy implications. As noted above, reducing gun ownership among law-abiding citizens will do almost nothing to reduce crime and violence directly, since violently criminal behavior is virtually nonexistent among persons without previous records of such behavior. The findings discussed earlier strongly suggest that reducing gun ownership among the law-abiding might well significantly reduce the risks of criminal behavior. A reduction in risks could in turn reduce the possible

52. Richardson, supra note 50 , at 33 .

53. Don Kates has also pointed out another benefit of civilian gun ownership related to burglary. If burglars avoid occupied premises partly because of possible victim gun ownership. confrontations between offenders and victims are minimized, and the frequencr of injur and death is thereby lowered among burglary victims for both those who own guns and those who do not. D). Kates, JR., Why Handgun Bans Can't Work 66 (1982).

54. Kleck \& Bordua, supra note 3 , at 282.

55. For a full analysis, see id. at 284-88.

56. Id. at 288 . 
criminal deterrent effect of widespread civilian gun ownership, especially regarding "gun-deterrable" offenses such as residential burglaries and commercial robberies. For these reasons, any "blunderbuss" measures aimed at reducing gun ownership in the general public seem ill-advised, at least until it can be shown that reductions in deterrent effects are counterbalanced by some benefit, such as reduced gun availability to criminals through theft and other transfers from law-abiding citizens. This benefit seems so marginal, however, that it may be difficult to demonstrate. ${ }^{57}$

\section{$\mathrm{V}$}

\section{Focus on Handguns? The Substitution of Deadlier Weapons}

In the context of gun control measures aimed at all types of long guns (such as rifles and shotguns) as well as handguns, weapon substitution refers to the possibility that offenders deprived of guns could substitute other, less deadly weapons. When the emphasis shifts to measures aimed exclusively or primarily at handguns, however, the substitution issue changes in a crucial way. An offender who has been blocked only from getting a handgun (or even more narrowly, a Saturday Night Special) is not likely to regard a knife or club as the best available substitute. Rather, his deadliest, most intimidating alternative, either for defensive purposes or for furthering a crime, is a rifle or shotgun. While these weapons are not as concealable as a handgun, concealability is not important to most gun crimes. For those crimes in which it is important, sawed-off shotguns or rifles generally provide sufficient concealability. Further, since the average handgun used in crime is of fairly good quality and correspondingly expensive, many rifles and shotguns are no more expensive than the handguns, making cost no obstacle to substitution. ${ }^{58}$

Long gun substitution is a very undesirable prospect because rifles and shotguns, depending on caliber or gauge and the ammunition used, can be anywhere from one and one-half to ten times as deadly as handguns. ${ }^{59}$ It is unlikely that criminals willing to violate the strongest social and legal prohibitions against violence would conscientiously opt for only the least deadly varieties of long guns and ammunition.60 Unless this occurred, however, the result of an effective handgun-only measure would be an increase in criminal homicide deaths.

57. Results from the Wright and Rossi survey of prison inmates indicate that while many criminals steal guns, they usually do so in order to sell rather than keep them, and those who do keep the guns for themselves usually already have a gun of their own. See J. Wright \& P. Rossi, supra note 27 (marginals for questions 82 and 83 ). Thus, although criminals frequently possess and use stolen guns in crimes, it is also apparently true that few criminals have to steal in order to get firearms.

58. Kleck, Handgun-Only Gun Control: A Policy Disaster in the Making, in Firearms and Violence. supra note 17 , at $167,187,192$.

59. Id. at 174 .

60. The same gencral point also applies to impulsive domestic homicides among supposedly "law-abiding" citizens. If the guns involved in such attacks are originally obtained for homc-and self-defense, it is unlikely that the long guns substituted for handguns would be the less deadly types. Many of the same qualities which make some types of guns desirable as offensive weapons also make them desirable as defensive ones. 
The precise extent of this increase would depend on two parameters: the fraction of assault-prone people, otherwise inclined to use handguns, who would substitute long guns in their assaults (the substitution fraction), and the ratio of the deadliness of the substituted long guns to the deadliness of handguns which otherwise would have been used in the absence of handgun controls (the deadliness ratio). The higher either parameter is, the more likely it would be that the net effect of the measure would be an increase in the number of homicides. If $X$ is used for the substitution fraction and $Y$ is used for the deadliness ratio, the relationship between the two has been computed as

$$
X=\frac{8649.19}{6827.53 Y-455.581}
$$

at the point where there is neither a net gain nor a net loss from the handgunonly policy. ${ }^{61}$ If $X$ is larger, then $Y$ must be smaller in order to prevent an increase in homicides. ${ }^{62}$

It is difficult to know for sure what type of long guns and ammunition would be substituted by criminals if handguns were not available, so the magnitude of the deadliness ratio is not certain. An estimate of three or four seems reasonable. That is, the substituted long guns would be about three to four times as likely to produce a death as handguns currently used in assaults. As to the size of the substitution fraction, the best estimate comes from the Wright and Rossi prison survey. ${ }^{63}$ Inmates were asked what they would do if they wanted to carry a handgun but could not obtain one. Among those prisoners who reported they had committed crimes with a gun "many times," "most of the time," or "all of the time," seventy-two percent said that they would carry a sawed-off shotgun or rifle instead. ${ }^{64}$ Substitution of long guns in ownership would almost certainly be higher, since many people would acquire a long gun as a substitute for owning a handgun, but would not carry it as frequently as they would their handgun. Thus, substitution in carrying might be about seventy-two percent but substitution in ownership could be anywhere from seventy-two to one hundred percent.

Nevertheless, if the substitution fraction $X$ is assumed to be 0.72 , then, solving the equation for $Y$, the deadliness ratio must be at or below 1.36 to avoid a net increase in homicides. That is, if seventy-two percent of the people who otherwise would have assaulted with handguns used long guns instead, and the other twenty-eight percent substituted knives, fists, and other nongun weapons, the handgun-only measure would lead to an increase in

61. This formula is based on the generous assumption that climination of handguns will $\mathrm{not}$ only affect the deadliness of assaults which do occur, but will also reduce the frequency of gun assaults by $25 \%$.

62. See Kleck, supra note 58, at 171-76, for a complete discussion of the derivation and computation of the formula.

63. J. Wright \& P. Rossi, supra note 27.

64. Telephone conversation with James Wright (July 26, 1983). 
homicides unless the substituted long guns were only 1.36 times as deadly as handguns, or less. This result could occur only if violent criminals paradoxically chose the least dangerous varieties of long guns, such as small caliber rifles (.243 caliber or less) or smaller shotguns (the .410 rather than 16-, 12-, or 10-gauge). There is no reason to expect such an optimistic outcome.

Of course, if handgun-only measures do not remove handguns from violence-prone people in the first place, the laws would be useless on that basis, there would be no need for substitution, and this whole issue would be moot. But the point is that even if such measures were effective in reducing handgun possession, they would almost certainly have the perverse effect of causing more people to die than would have died without the measure. This analysis has the clearest possible policy implication: Under no circumstances should restrictions be placed on access to handguns (or specific types of handguns such as Saturday Night Specials) without equally severe restrictions on access to long guns. ${ }^{65}$

State or Federal Controls?

Because there are so many state laws regulating firearms, gun control opponents often ask why any federal laws are needed. Gun control supporters reply that state laws are often ineffective because they are easily evaded if bordering states do not have equally restrictive controls. The primary justification for federal controls is the interstate "leakage" of firearms. For example, Newton and Zimring stated that "[s] state and local regulation have consistently been frustrated by the flow of fireams from one state to another." 66 Beyond this problem, supporters of federal gun control rarely mention any other justification for national measures.

One would think, then, that the only kind of federal legislation necessary to supplement state controls would be a statute aimed at stopping the interstate flow of firearms to unqualified buyers. Such persons could not, as a result, travel from their own restrictive states and obtain guns in less restrictive states, and residents of lenient states could not otherwise transfer firearms to unqualified recipients residing in restrictive states. Ideally, the federal legislation would give those states with a need for restrictive gun control measures a fighting chance to make them work.

Yet, many advocates of federal controls go far beyond such measures. In their report to the National Violence Commission, Newton and Zimring

65. The same general argument applies to measures aimed at the cheap small-caliber handyuns known as "Saturday Night Specials," since such measures encourage substitution of larger-caliber. better quality, and therefore deadlier, handguns. There is even less difference in concealability and ease of carrying between Saturday Night Specials and other handguns, however, than there is between handguns and sawed-off long guns, thus allowing substitution in an even higher percentage of assault situations.

66. G. NewTon \& F. ZimRing, supra note 2, at 95. 
recommended a federal restrictive licensing standard amounting to a virtual ban on private ownership of handguns. ${ }^{67}$ Rather than simply supplementing state measures and thus making it possible for states effectively to apply whatever gun control measures they regard as necessary, such a far-reaching proposal is a substitute for state controls, a way of overriding state legislatures' unwillingness to pass more restrictive laws of their own.

There are several good reasons to reject this approach. First, the concept of federalism implies that the states should have as much autonomy as possible in drafting their criminal law and other statutes. Second, federal controls are less satisfactory because traditionally there has been a very limited federal law enforcement apparatus in the area of ordinary crime. The Federal Bureau of Investigation (FBI) regards itself more as an investigatory than a law enforcement agency. Nothing at the federal level corresponds to a street police force, and local police agencies, where most law enforcement personnel are concentrated, have generally been reluctant to devote their limited resources to the enforcement of federal laws. Third, the need for gun control differs sharply from one state to another. Some states have almost no violent crime, with or without guns, while others have a great deal. For example, in 1981 South Dakota had only twelve murders and nonnegligent manslaughters and 122 robberies (1.8 and 17.8 per 100,000 population, respectively), while Nevada, with only twenty-three percent more people, had 148 homicides and 3,867 robberies (17.5 and 64.9 per 100,000, respectively). ${ }^{68}$

Nevertheless, the Gun Control Act of 1968 (GCA), ${ }^{69}$ the only major federal gun legislation in the last forty-five years, was generally limited simply to reinforcing whatever controls each state has by prohibiting out-of-state purchasing by its residents. Unfortunately, a number of loopholes in the GCA render this attempt to stem the interstate flow of firearms between nondealers ineffective. For example, although the Act made it unlawful for licensed dealers to sell "any firearm to any person who the licensee knows or has reasonable cause to believe does not reside in . . . the state in which the licensee's place of business is located,"70 it did not require dealers to verify a buyer's residence by, for example, demanding a driver's license or similar identification. ${ }^{71}$ Although some states require dealers to verify residency, dealers elsewhere can sell guns to persons from more restrictive states as long as they do not know or have reason to believe that the buyer is a resident of another state. The GCA also made it generally unlawful for persons not licensed as dealers to buy guns in one state for transport to, and sale in, another state, but did not provide any effective means for enforcing the

67. Id. at $143-44$.

68. UCR (1982), supra note 16 , at 51,55 .

69. Pub. L. No. 90-618, 82 Stat. 1213 (1968) (codified at 18 U.S.C. $\$ \$ 921-928,26$ U.S.C. $\S \S 5801-5802,5811-5812,5821-5822,5841-5849,5851-5854,5871-5872,6806,7273$ (1982)).

70. 18 U.S.C. $\$ 922$ (b)(3) (1982) (emphasis added).

71. S. Brill, Firearm Abuse: A Research and Policy Report 176 (1977). 
provision. ${ }^{72}$ Further, the act allows almost any adult to receive a federal firearm dealer's license for a ten dollar annual fee, as long as the applicant claims he is going to conduct business from some premises (which presumably could include his home). ${ }^{73}$ As a result, there were 157,655 federally licensed firearms "dealers" by January 1, 1981 but probably fewer than 4,000 Treasury inspections over that year. ${ }^{74}$ This situation made it very easy for licensed dealers to purchase legally large numbers of guns in less restrictive states and to transport them into more restrictive juridictions, where the less reputable among the "dealers" could sell the guns to buyers who would not qualify for legal gun acquisition in the more restrictive states. The GCA also left unlicensed individuals free to sell their guns privately, rather than requiring them to go through licensed dealers, thereby making it very difficult to check on the validity of such sales. Among other things, it is virtually impossible to hold a private citizen liable for selling firearms even to hardened criminals, because it cannot be proven that the seller knew about the criminals' felony records. Consequently, both criminals and ordinary residents who cannot obtain permits in their own restrictive states can rely on guns from out-of-state sources. ${ }^{75}$

Given that there are probably over 160 million guns now circulating in private hands in the United States, ${ }^{76}$ it is unclear to what extent federal restrictions on interstate trade can prevent criminals from obtaining guns. Nevertheless, whatever enforcement potential that does exist could be maximized by a few straightforward revisions to the GCA. Licensed dealers could be required to verify buyers' in-state residence by examining drivers' licenses or other suitable identification, as is already done in many states. The federal dealer's license fee could be raised to $\$ 500$, as proposed in the Kennedy-Rodino bill, ${ }^{77}$ thereby reducing the number of people who can legally transfer guns across state borders. In addition, private gun sales could be brought under closer control by a requirement that such transactions occur only through a licensed dealer. Beyond controls on interstate trafficking, controls at the state level are about as likely to succeed in keeping guns from criminal users as are federal restrictions.

\section{VII \\ Enforcement of Gun Control Laws}

Although gun control laws in the United States are often contrasted with supposedly much more restrictive laws in Europe, most of the U.S. population lives in jurisdictions subject to at least moderate restrictions. For example, at least seventy percent of the population is subject to acquisition or purchase

\footnotetext{
72. 18 U.S.C. $\$ 922(\mathrm{a})(1982)$.

73. 18 U.S.C. $\$ 923(\mathrm{a})(3)(\mathrm{C}),(\mathrm{d})(1)(1982)$.

74. See P. Shields, Guns Don't Die-People Do 182 (1981).

75. See S. BRILL, supra note 71 . at 82-93.

76. Kleck, supra note 17 , at 127.

77. Handgun Crime Control Act of 1979, H.R. 7148, 96th Cong., lst Sess. (1979).
} 
requirements and sixty-six percent is subject to a police check before or after purchasing a handgun. ${ }^{78}$ Yet, beyond arrests for illegally carrying firearms, there is very little criminal justice activity directed specifically at enforcing gun control laws as we have defined them.

For example, in Illinois police made an average of 3,142 arrests per year for "unlawful use of a deadly weapon" (mostly carrying a concealed weapon) over the 1972-1976 period, yet only 269 arrests per year were made for unlawful possession and 537 per year for ownership of a gun without the required state firearms owner's license. ${ }^{79}$ Significantly, Illinois is a state estimated to hold at least 1.7 million individual adult gun owners, of which twenty-eight percent were without the required gun owner licenses ${ }^{80}$-about half a million people eligible for arrest for illegal possession or ownership of a gun without a license. Arrests on gun charges were evidently made almost exclusively incident to arrest on some other charge. For example, a person might be arrested for robbery or carrying a concealed weapon and then incidentally also be charged with illegal possession. ${ }^{81}$ These figures suggest that there is little specialized enforcement effort directed at gun law violations.

When gun violation arrests are made, prosecutors achieve few convictions, and when a rare conviction is obtained, judges rarely impose sentences requiring even short terms of incarceration. In Chicago, which has a local gun registration ordinance which goes beyond Illinois' already fairly strict gun laws, only four percent of persons charged under the local registration law were convicted and only twenty-two percent were convicted on charges under the state licensing law, for the period 1968-1973. Of those convicted, only twelve percent received sentences involving any jail time, with a mean jail term of thirty-six days. ${ }^{82}$ Even in New York City, with its extremely strict gun control laws, stiff penalties are rarely imposed. Although sixty-four percent of arrests for felony handgun possession result in conviction on some charge (not necessarily a felony charge), an analysis of a sample of such arrests indicated that out of twenty-eight gun possession felony cases reaching disposition, only two resulted in a sentence of felony time, while another six resulted in a sentence with some jail time on a reduced misdemeanor charge. ${ }^{83}$ In sum, police, prosecutors, and judges apparently give little priority to vigorous enforcement of existing gun control laws.

This behavior is perfectly understandable given the larger context of the criminal justice system's tasks and available resources. Prisons are filled with

78. J. Wright, P. Rossi \& K. Daly, Under the Gun: Weapons, Crime and Violence. in AMERICA 269-70 (1983).

79. D. Bordua, A. Lizotte \& G. Kleck, Patterns of Fireakms Ownership. Use and REgulation IN ILIIINOIS 79 (1979).

80. Id. at $94,101,167$.

81. See Bendis \& Balkin, A Look at Gun Control Enforcement. 7 J. Pol.ıce SCI. \& AD. 439, 44-47 (1979).

82. See id. at $443,446$.

83. Vera Institute of Justice, supra note 22, at 119. 
serious repeat offenders, so judges are reluctant to send gun violators to prison. With limited prison capacity, sending someone to prison for a mere gun violation necessitates paroling or otherwise releasing a serious criminal into society. Given that few gun convictions will result in an offender's removal from the streets, many prosecutors are undoubtedly reluctant to devote their limited resources to prosecuting a gun case. It is more likely that the gun charge will at best serve as a bargaining chip to persuade defendants to plead guilty to other charges while the gun charge is dropped. Knowing all this, police officers are not anxious to expend their time on gun violation arrests and the associated paperwork.

Of course, expanding available resources can always make a difference. Given the scale and seriousness of crime facing the system, however, with killers, rapists, armed robbers, and burglars going uncaught, unconvicted, and unpunished, it is unlikely that any marginal increase in money and manpower will be devoted to catching and imprisoning people who have purchased a gun without a permit or sold a gun to an unqualified buyer. But there is an alternative. In some circumstances, additional resources can be assigned specifically to gun law enforcement. For example, specialized units in the police department and the prosecutor's office can be established for the sole purpose of enforcing gun laws, as has already been done to some extent for other crimes. Separate gun courts can be established to deal with these cases, reducing the probability that other cases will push gun cases aside and reducing also the incentive to bargain away gun charges. Chicago has established such a gun court. Nevertheless, judges will still be reluctant to assign prison sentences to gun violators as long as there is not enough prison space available for murderers and rapists. Indeed, this attitude reflects exactly how some of the Chicago gun court judges feel, especially when faced with first-time offenders whose only crime was a gun violation. ${ }^{84}$ In addition, establishing these specialized units still must involve someone making the decision to devote some resources to gun violations rather than other crimes, whether it is police administrators, district attorneys, city councils, or state legislatures.

The low priority police and prosecutors assign to enforcement of gun control laws may, in many jurisdictions, be directly attributable to the "blunderbuss" character of the existing statutes. Don Kates has pointed out that police and prosecutors routinely deal with very serious offenders, but with gun violations they often find that they are dealing primarily with respectable citizens. Kates believes that this experience causes enforcement personnel to deprioritize gun control enforcement to an extent that would not be true for narrower laws targeted at persons universally regarded as unfit to own guns, such as convicted felons. ${ }^{85}$ The less gun control laws focus exclusively on the "bad guys," the less enthusiastic police and prosecutors will be to enforce those laws.

84. Shields, Tüo Judges Look al Gim Control, 57 ChiCago Bar Record 180, 184 (1976).

85. Personal communication from Don Kates, Jr. to the author. 
Thus, as long as current enforcement priorities prevail, there will be little enforcement of existing gun laws, regardless of available resources. If this is true for the relatively modest laws already in place, it is unlikely to be any different for the proposed laws. Also, if new laws are enacted, either enforcement priorities within the criminal justice system must change, or the laws must somehow be made effective with the current minimal level of enforcement, relying largely on voluntary compliance. Nevertheless, current enforcement priorities are not carved in stone. To change existing priorities requires only that criminal justice system personnel change their opinions regarding the value of enforcing gun laws. All enforcement is necessarily selective, and the selectivity generally operates so as to give the most severe treatment to the most serious and repetitive offenders, at least insofar as official records accurately index the offenders' prior criminal behavior. ${ }^{86}$ Therefore, one clear incentive to criminal justice system personnel for the enforcement of gun laws is the opportunity to incarcerate repetitively violent offenders for illegal possession or ownership of firearms, especially when the criminals cannot be convicted on any other charges. Until and unless this perception becomes widespread, however, the introduction of further gun controls will effect the availability of firearms to the violence-prone only to the extent that the controls can be achieved through voluntary compliance.

\section{VIII}

\section{How Do Criminals Acquire Guns?}

If the primary proximate goal of gun control law is to reduce gun possession among criminals, then to devise effective controls requires an understanding of how criminals acquire firearms. Patterns of acquisition clearly vary by criminal type and also from place to place, partly because of variation in prevailing gun regulations. Consequently, research findings necessarily must be somewhat locale-specific and are not as easily generalized as one might hope.

Gun control efforts would be advanced if criminals obtained their guns mainly from either licensed dealers or from theft, since the former constitutes a highly visible, regulatable source, and local police agencies are equipped for and committed to conventional law enforcement which will deal with the latter. Indeed, some pro-control analysts such as Mark Moore, a former official of the federal Drug Enforcement Administration, have attempted to offer support for such an optimistic picture. Relying on information from the files of the Bureau of Alcohol, Tobacco and Firearms (BATF), Moore asserted that "private transfers do not emerge as a major sector supplying guns to offenders." 87 Yet Moore himself characterized the BATF information as "bad data" which described a "biased" sample of illegal gun dealers and which was "biased toward paths [between original sources and offenders] that can be

86. See. Kleck, Racial Discrimination in Criminal Sentencing. 46 Aм. Soc. REv. 783, 789, 792 (1981)

87. Moore, Kepping Handguns from Criminal Offenders, 455 AnNals 92, 106 (1981). 
conveniently investigated." 88 He justified his reliance on the BATF data by noting the absence of better information, an accurate observation at the time. Because good information on the subject has since been gathered, however, we may now dispense with the flawed BATF data.

James Wright and Peter Rossi went to the "horse's mouth" by surveying convicted criminals in prisons in ten states about where and how they got their guns. The results indicated that, contrary to Moore's optimistic conclusions, criminals acquire their guns predominantly through private, second-hand transfers. These transfers could be described as "quasi-legal" in that, although not involving theft, they often violated federal or state regulatory provisions (especially in jurisdictions with strict controls). According to the convicts, theft accounted for only a small fraction of the guns they needed for use in crimes. That is, few criminals acquired guns by theft at a time when they did not already have a gun. Similarly, acquisitions through licensed firearms dealers account for only a small fraction of gun acquisitions. Of all the convicts who had ever owned or possessed a handgun, only thirty-two percent had acquired their firearms by theft, forty-three percent had purchased them for cash, while twenty-three percent borrowed them, traded for them, or received them as gifts. Only twenty percent of the convicts got their handguns from a gun shop, pawnshop, hardware or department store; the rest acquired them from private sources or by theft. ${ }^{89}$ The same picture emerges from the findings of a Florida survey of prison inmates. The Florida study showed that only thirty percent of handgun murderers and assaulters reported acquiring their guns from dealers, fifteen percent admitted stealing them, and seven percent did not know where their guns came from-while forty-seven percent had obatined their guns from private sources. ${ }^{90}$

Although over 100,000 handguns are stolen each year from individuals ${ }^{91}$ and about twenty to twenty-two percent of firearms confiscated by police (usually in connection with gun violations) were reported stolen at some time in the past, ${ }^{92}$ stolen guns are nonetheless apparently not an important source of firearms for criminals, at least not in the ten states covered in the Wright and Rossi prison survey. Of the total sample of 1,954 prisoners interviewed, only 790 (forty-two percent) admitted to having ever stolen a gun. Of these, only 524 (sixty-six percent of the gun thieves, twenty-eight percent of the whole sample) had ever kept a gun for themselves, rather than selling it for profit or otherwise disposing of it. Of those inmates who had stolen a gun, seventy percent usually stole to sell or trade, rather than to acquire one for personal use. Most gun thefts are haphazard affairs; few thefts are the result

88. Id. at 102,106 .

89. J. Wright \& P. Rossi, supra note 27 (marginals for questions 123 and 124).

90. Burk, Handiun Regulation app. 45 (1977).

91. S. BRILi. supra note 71 , at 104.

92. Id. at 103. Bul $f$. U.S. Bureau of Al.cohol, Tobacco \& Firearms, Project Identification: A Study of HANDGuns USED in Crime 21 (1976) (tracing indicated that only six percent of handguns had been reported as stolen). 
of a specific need for and intent to acquire a gun. Only eleven percent of the prisoners answering the relevant questions had ever gone out looking specifically for a gun to steal; most gun thieves stole guns only when they came across them in the course of stealing cameras, color televisions, and other portable valuables. When a criminal did steal a gun and keep it for himself, the reason usually was not that he did not have a gun. Only 187 inmates (twenty-four percent of the gun thieves, ten percent of the entire sample) reported ever having stolen a gun for that reason. ${ }^{93}$ In short, few of the inmates found it necessary to steal in order to obtain a gun.

It might be argued that while criminals do not often acquire guns directly by stealing, they frequently acquire, by quasi-legal transfers from friends, acquaintances, or others, guns stolen by someone else earlier in the chain of transactions ending with the gun in the criminal's hands. There is undoubtedly some truth to this assertion, but available data indicate it does not alter our conclusions significantly. Efforts have been made to determine what fraction of guns confiscated by police had been stolen at some point since their manufacture. The most intensive of these efforts indicated that only $19.5 \%$ of confiscated handguns had been stolen at any point in the past. ${ }^{94}$ Of course, a gun might have been transferred five or six times before, with only one of the transfers being a gun theft. From Wright's data, we also know that when a theft does occur, it is usually incidental to a burglary not targeted at obtaining guns and committed by a criminal who already had at least one gun. Therefore, if gun theft could somehow be eliminated entirely, it evidently would have only a slight effect on the extent to which criminals would be armed with guns.

Even for the small minority of criminals who obtained their guns through theft when they had no other gun, there is no empirical indication that they could not have gotten guns through some other nontheft channel. As to the criminals who obtained their guns through purchase or trade from nonlicensed sources, there is no indication that they had to go to black market sources specializing in illegal gun sales. Of the 943 criminal handgun owners, only twenty-seven $(2.9 \%)$ reported getting their last handgun from a "black market source" and only forty-four (4.7\%) said they got it from a "fence.",95 Black market enterprises, of any scale, are apparently of little importance as a source of guns for criminals. Consequently, the emphasis placed on black market "enterprises" and "illegal firms" by some authors ${ }^{96}$ is misplaced and of little relevance to criminal gun acquisition.

By far, the most common means of gun acquisition mentioned by Wright and Rossi's respondents were "from a friend" (370 out of the 943 , or thirtysix percent) and "off the street" (137 cases, or fifteen percent). Another $4.5 \%$

93. J. Wright \& P. Rossi. supra note 27 (marginals for questions $81-83 \mathrm{a}$ and 123).

94. S. BRII.1., supra note 71 , at 102-03.

95. J. Wright \& P. Rossi, supra note 27 (marginals for question 124).

96. E.g. Moore, supra note 87, at 100-05. 
obtained guns from a member of their family ${ }^{97}$ Thus, most criminals get their guns through purchase or other quasi-legal transfers, rather than by theft; from friends, family, or acquaintances on the street, rather than from licensed dealers or black market enterprises. Given this reality, how can guns be kept from criminals? There are at least two general strategies which go beyond existing state and federal regulation of licensed dealers.

First, gun possession by criminals can be made more legally risky by raising associated legal penalties, by raising the probability of detection of such possession, or both. This deterrence strategy is aimed at reducing criminals' desire or motivation to obtain guns, regardless of their availability. This approach would require a significant effort to enforce existing legal prohibitions, implicating many of the enforcement problems raised earlier in this article. Such prohibitions are already in place. Under federal law, possession of a firearm by a convicted felon is a felony punishable by up to five years in prison. ${ }^{98}$ In addition, the law of twenty-two states prohibits convicted criminals (usually felons) from possession or purchase of any kind of firearm, while in another twenty states, only handguns are prohibited to this group. ${ }^{99}$

The second strategy involves reducing gun availability by reducing the number of willing, unlicensed private firearms sellers. Given that most of the private gun transfers seem to involve small-scale, even one-time sellers, conventional law enforcement efforts, either proactive or reactive, are not likely to be cost effective or efficient. Another method for dealing with the problem, however, was incorporated into the Kennedy-Rodino bill. ${ }^{100}$ This bill required all handgun transfers to be channeled through a licensed dealer, who would be required to insure that a would-be gun recipient was legally eligible to receive and possess the weapon, according to prevailing federal and state requirements. ${ }^{101}$ The measure was given force by establishing civil liability for dealers who knowingly transfer a handgun to an ineligible person and for private individuals who transfer a handgun illegally, that is, not through a licensed dealer. ${ }^{102}$ Such persons could be held liable for any damage the new gun owners caused with the illegally transferred weapon.

While the Kennedy-Rodino approach would leave room for sufficiently motivated sellers to transfer their guns to unqualified recipients, such a measure could deter some transfers by casually motivated sellers without any substantial commitment of law enforcement resources. The effect of these provisions would be to channel at least some fraction of the private,

97. J. Wright \& P. Rossi, supra note 27 (marginals for question 124).

98. 18 U.S.C. $\$ \S 922(\mathrm{~h}), 924$ (a) (1982).

99. See Staff of Senate Comm. on the Judiciary, 97th Cong., 2d Sess., Report on Federai. Regulation of Firearms 204-05 (Comm. Print 1982). The survey of state firearm control laws included in this report was done by Kent M. Ronhovde and Gloria P. Sugars.

100. H.R. 7148, 96th Cong., 1 st Sess. (1979). This legislation would, because of the substitution factor, be effective only if made applicable to transfers of all types of fircarms, not just handguns.

101. Id.

102. Id. 
secondhand traffic in guns into more visible and regulatable dealer channels while motivating dealers to screen out ineligible would-be gun recipients. ${ }^{103}$ But this measure need not be applied at the federal level, through legislation such as the Kennedy-Rodino bill, and certainly should not be limited to handguns, for reasons made clear earlier in this article.

In states which have permit-to-purchase, application-to-purchase, or owner license laws, the liability provision could be used in combination with a provision obligating dealers to examine the required documents before transferring the gun. In this way, there would be a practical means for dealers to know whether a recipient was eligible. A dealer would not be liable for damages if he was shown forged documents or otherwise could not reasonably have been expected to know the recipient was ineligible. Undoubtedly, many private persons would still illegally transfer guns directly to ineligible persons, either because they owned so few assets that they would stand to lose very little if sued, or because they did not think that the gun could be traced back to them if it were subsequently involved in injury or damage. Nevertheless, even partial compliance could reduce the availability of guns to criminals enough to justify the costs of the added caseload in civil courts and the additional inconvenience to dealers and private sellers of guns.

\section{IX \\ Summary of the Policy Lessons}

A careful reading of recent gun control research suggests the following tentative conclusions for public policy:

(1) Gun control laws should be aimed at restricting gun possession among persons with prior records of violence rather than among the general public. Otherwise, loss of the deterrent effect on crime exerted by widespread civilian gun ownership could outweigh the benefit of a slight reduction in gun possession among the violence-prone.

(2) Gun control restrictions should be applied equally to all types of firearms, not just to handguns or "Saturday Night Specials." An inclusive approach would avoid inadvertently encouraging the substitution of deadlier weapons, a distinct possibility not precluded by marginal differences in concealability between the gun types.

(3) Beyond amending the Gun Control Act of 1968 to make evasion of state gun control laws more difficult, further legislation at the federal level is unnecessary, given the greatly varying need for gun control among the states.

(4) Unless the priority criminal justice system personnel assign to enforcing gun laws changes, any additional enactments must depend primarily on voluntary compliance for their effectiveness. It is doubtful whether additional resources would be made available for

103. See Cook \& Blose, supra note 29 , at 89-90, for an excellent discussion. 
enforcement of gun laws, unless the revenues were somehow specifically attached to specialized gun law enforcement agencies.

(5) Gun control measures must deal with the fact that criminals obtain their guns primarily through private, quasi-legal transfers from private parties such as friends or acquaintances "on the street," rather than from licensed dealers, black market enterprises, or through theft. Such transfers might be minimized by establishing civil liability for damages resulting from an illegal gun transfer to an ineligible recipient. Transfers of firearms would be channeled through dealers who would be required to examine certain legal documents (driver's license, purchase permit, owner's license) to establish that the recipient was eligible. Persons who transferred guns in any other manner would be liable for damages caused with the gun by any ineligible recipient to whom they transferred the gun.

What sort of gun control measures do these lessons imply? They suggest a moderate measure with many features already enacted in one form or another in many states, although not yet in a single integrated package. What is called for is a law establishing a well-enforced state-level permit-to-purchase or license-to-possess requirement applicable to all types of firearms. The law would forbid possession or acquisition of any firearm by persons with a criminal conviction for a felony or violent misdemeanor in the past seven years or psychiatric institutionalization for a violent act during that period, and by fugitives from justice. A check of whatever criminal and psychiatric records were available would have to be completed before any permit or license could be issued. Persons under the age of eighteen would be forbidden from acquiring firearms or ammunition except from members of their immediate family for use while under adult supervision. Individuals who illegally transferred a gun to a person ineligible for firearms acquisition or possession would be subject to civil liability for damages caused with that gun by the ineligible recipient.

This set of provisions would not prevent law-abiding citizens from obtaining any type of firearm currently available and would add only slight inconvenience to such acquisitions, which are very infrequent transactions for all but a few citizens. The cost of screening applicants for a license or permit would not be great. For example, Cook and Blose ${ }^{104}$ report that a record check for prior convictions or psychiatric institutionalization costs only $\$ 1.90$ in Illinois, where a completely automated system is already in use. In combination with a tightened-up federal Gun Control Act and improved computer criminal record files, these sorts of state screening systems at least hold the potential for producing modest reductions in gun possession among violence-prone persons who are only marginally motivated to acquire guns. It is unlikely that much more than this can be done to reduce violence through gun control laws.

104. Id. at 89 . 
Thinking seriously about violence reduction requires going beyond what currently seems politically easy or "realistic." Orthodox crime control programs devised within the framework of traditional political realities have been failures and similar proposals for the future show no prospects of doing any better. Policies aimed at increasing or redistributing police manpower, imposing long prison sentences, increasing the incapacitative impact of the prison system, reducing due process restraints on police and prosecutors, and generally spending more on criminal justice are all acceptable to most political elites, enjoy widespread public support ${ }^{105}$-and are doomed to failure as a means for producing significant reductions in serious crime. ${ }^{106}$ The same seems to be true of gun control laws, although the evidence on this issue is not as strong. ${ }^{107}$

To accomplish a significant reduction in violence will require a return to serious consideration of the fundamental social and economic causes of violent behavior, a course which criminologists have repeatedly advocated for decades. This approach has been derided by some as a search for causes which public policy cannot directly affect. ${ }^{108}$ Nothing could be further from the truth. For example, research on domestic violence, surely one of those types of crimes assumed to be incapable of control through public policy, shows that it is strongly related to family economic conditions. The best study of this subject used interviews with a representative national sample of households and found that "unemployed men are twice as likely to use severe violence on their wives as are men employed full time, and men employed part time have a rate of wife-beating three times the rate of full-time employed men."109 Given that unemployment is strongly related to violent behavior and that reducing unemployment is a well-established goal of public policy, it is ridiculous to suggest that we must rely on gun control laws, or indeed any strategies using criminal law or the criminal justice system, to reduce violence. While it may logically make sense to use a variety of methods to deal with the problem, the political realities are such that attention paid and resources devoted to one strategy tend to divert attention and resources away from other, possibly more productive, strategies. More expensive alternatives will never be given serious consideration as long as policymakers and the general public continue to believe in the efficiency of the criminal justice approach.

Nor is it valid to say that gun control and other criminal-justice-systemoriented strategies are the only currently available ways to deal effectively with crime in the short term. Strategies directed at reducing unemployment, poverty, and inequality have every bit as much potential for producing shortterm results as criminal justice system strategies. Producing short-term decreases in poverty and unemployment is difficult, not impossible. For

105. U.S. Bureau of Justice Statistics, supra note 20, at 220-78.

106. See S. Walker, Sense and Nonsense About Crime: A Policy Guide (1985), for a wideranging debunking of such strategies.

107. J. WRIGHT, P. Rossi \& K. Daly, supra note 78, at $308,317$.

108. E.g., J. Wilson, Thinking About Crime 42-57 (rev. ed. 1983).

109. M. Straus, R. Gelles \& S. Steinmetz, supra note 25, at 150. 
instance, recent sophisticated evaluation of the Job Corps, a federal program aimed at the "hard-core" poor, shows that males who completed the program not only were receiving an average of $\$ 23.24$ more per week during the follow-up period than matched nonparticipants, but also experienced eight fewer arrests per 100 Corpsmembers than the control group. ${ }^{110}$ Given the minimal investment in programs of this sort, it is surprising that they achieve any success at all, 111 but they can in fact produce significant results in a short period of time. Therefore, a more promising strategy for reducing violence and crime would be one aimed at reducing the entry of underclass adolescents into criminal careers by:

(1) the creation of jobs for which adolescent and young adult members of the underclass can be trained, and

(2) training the target group for those jobs. Massive numbers of jobs can be created through federally funded construction projects aimed at a much-needed rebuilding of our nation's infrastructure, especially its crumbling highways, bridges, railroads, and urban transit systems. The Job Corps provides a model for the training component of the program. Sufficient resources are available for the program, without tax increases, through reallocation of federal tax money from the bloated defense budget.

Job creation aimed at the underclass has not been attempted on even a modest social scale. The few small efforts in this regard have been moderate successes, despite the aura of failure generated by hostile publicity. Acknowledging the drastic limitations of criminal justice crime control alternatives must be the first step toward making crime control through underclass job creation a respectable part of the mainstream political agenda.

110. J. Thompson, M. Suiridoff \& J. McElroy, Employment and Crime: A Review of Theories AND RESEARCh 176-83 (1981).

111. For example, even in 1972 when it was still funded at a relatively high level, the Job Corps program claimed only $\$ 202$ million, or $0.09 \%$, of the federal budget. That figure represented only $1.7 \%$ of spending on criminal justice at all levels of government. Indeed, the combined budgets of all federal work and training programs, most of them primarily benefiting middle class persons. claimed funds equalling less than one quarter of total criminal justice spending. U.S. BUREAt: OF THF Census, Statistical Abstract of the United States 1976, at 144, 160. 